\title{
ETHNOGEOGRAPHIC AND CULTURAL CHARACTERISTICS \\ OF UKRAINIANS IN VOJVODINA AS SUSTAINABILITY FACTORS OF THEIR NATIONAL IDENTITY
}

\author{
DOI: http://dx.doi.org/10.18509/GBP.2020.55 \\ UDC: 314.15(497.113:=161.2)"19/20" \\ 323.1(497.113:=161.2)"19/20"
}

\author{
Bojan Đerčan \\ Milka Bubalo Živković \\ Bojana Kalenjuk \\ Tamara Lukić \\ Department of geography, tourism and hotel management, \\ Faculty of Sciences, University of Novi Sad, Serbia
}

\begin{abstract}
The paper analyzes the spatial distribution of Ukrainians in Vojvodina, demographic characteristics, ethno-cultural features in order to preserve the national identity of this small ethnic group in Vojvodina. According to the 2011 census report, there were 4.202 Ukrainians, mostly in the municipalities of Kula, Vrbas, Sremaska Mitrovica, Novi Sad and Inđija. The history of this East Slavic people in this region dates back to the time of the Habsburg Monarchy, when, after the liberation of southern Hungary from the Turks, they moved to these territories. From the territory of present-day Ukraine in 1745 the migration of the Slovenian peoples to Bačka, Srem and Slavonia began. They belong to the recent Ukrainian immigrant community. Most of the colonists settled on the territory of Bosnia and Herzegovina, after which the Ukrainians made contacts with the Rusyns in the territory of Vojvodina, with whom they shared the same religion and similar language. After migration from Bosnia to Serbia, especially after the Second World War 1945-1946. In the 1990s, Ukrainians mostly occupied settlements in Bačka and Srem.
\end{abstract}

Keywords: Ethnic group, national identity, Ukrainians, Vojvodina, multiethnicity

\section{INTRODUCTION}

In the 1920s, nearly 70,000 refugees from Ukraine and southern Russia found refuge in the Kingdom of Serbs, Croats and Slovenes. The settlers included about 40,000 soldiers and about 30,000 civilians. It is estimated that there were over 30,000 Ukrainians among these migrants, by origin or place of birth. Initially, these refugees were housed in about 300 colonies throughout the Kingdom. It was not until 1924 that they obtained the right to freely choose their permanent residence. Most of them opted for Serbia, and Ukrainians from Western Ukraine mostly opted for Belgrade, Vojvodina, Slavonia and Zagreb. Belgrade was dominated by the Russian refugee environment. Since imperial Russia had been envisaged as a national-political monolithic empire since the 17th century, in the Serbian environment all settlers were perceived as Russians [1].

Most Ukrainians who immigrated to Serbia in the 1920s, moved to Western Europe and overseas countries after 1944/45. A number of their descendants still live in Serbia and the former Yugoslavia [1] [2]. 


\section{MIGRATIONS OF UKRAINIANS IN HISTORICAL CONTEXT}

The only recognizable Ukrainian national minority living in Serbia today did not emigrate directly from Ukraine. The current Ukrainians in Serbia, who live predominantly in Vojvodina, come from the migration movements of Ukrainians from Bosnia, from a time when Bosnia and Herzegovina and Serbia all were parts of Yugoslavia. Until 1878, Bosnia and Herzegovina was under Turkish rule. After the Congress of Berlin, it was occupied by the Austro-Hungarian Monarchy and annexed in 1909. Immediately after the occupation and establishment of the Supreme Earth Administration in 1879, systematic colonization began. The term "colonization" meant organized settlement on pre-prepared terrain, on which the colonists were granted certain privileges and benefits [1].

After the Germans, most of the colonists were the Ukrainians. The Polish, who immigrated to Silesia after 1946, were settled with this ethnic group on the basis of agreements between the governments of the Federal People's Republic of Yugoslavia and the Republic of Poland. Along with this migration to Bosnia, Slavonia was inhabited, but in a much smaller number. The settlers were from Galicia, and to a lesser extent from Northern Bukovina and Zakarpattia. This relocation was considered an "internal" colonization since these regions had been under Austria since 1720.

The largest number of Ukrainians immigrated in the period 1898-1901. However, individual settlements lasted until the beginning of the First World War. The Ukrainians came to Bosnia under the name of the Ruthenians, called themselves Ukrainians, and the indigenous population called them Galician. The first settlers received free state land under the forest, the so-called "empire". To get arable land, they had to clear forests. They had to hand over the timber to the state, with the right to retain the timber for the construction of houses and farm buildings. In the early years, they were tax-exempt - they didn't have to pay so called dozens, and later they paid those taxes only in years which weren't dry. These benefits, though modest, did not last long. Settlement regulations changed rapidly at the expense of the colonists. Families who later settled did not receive the land and had to buy it. These purchases were unorganized and up to 600 crowns were paid for one property. New locations were remote and scattered across wide spaces, often in deserts, with no roads. The wait to determine their location and plot sizes took a very long time. While waiting, life was very difficult. Families lived in Turkish inns, under tents, even under clear skies. Money acquired from selling properties in Ukraine was quickly spent, partly on the trip and mostly on expensive living. The situation was also exacerbated by lack of knowledge of the language, poor housing for many families, hunger, illness, a large number of deaths, the intolerant attitude of the indigenous population and other distresses. This led people to become desperate and hopeless. Some families moved back to Ukraine and some extended to Europe and overseas. It was the most difficult period of life for immigrants in the new environment [1] [2] [3].

The primary administrative center of Ukrainian colonization was Prnjavor, which later became the center of gathering of displaced families. Immigration to the municipality of Prnjavor began in 1898, and it intensified in 1900. These were Ukrainians from Galicia, mainly from the municipalities of Tovmach, Brody, Ternopil, Rogatin, Buchach, Rava Ruska and others. Several families arrived from the Carpathian Ukraine. In addition to Prnjavor, the villages of Babinci, Karače, Ilova, Macino Brdo, Okolje, Moravica, Ratkovac, Radunovac, Konjugovci, Galipoljci, Lužani, Vučjak, Štrpci, Drenova, Palaškovci, and Ukrainan Lug named after the Ukrainians. Approximately at the same time, the settlement of Devetina, Kamenica, Dubrava, Brezik, Hrvačani, Prosek, Potočan, Drugović, Lišnja, Moravica, Vršan and other settlements began. Derventa and the 
surrounding towns (Kukavica, Baščari, Živinice, Plehan, Bijelo Brdo, Kulinovci, Agići, Miškovci, Detlak and towns from Brod to Sarajevo) have been gradually inhabited by the Ukrainian population since 1898. These were immigrants from Zbaraž, Lozova, Zboriv, Podgajce, Peremyshl, Berezan, Brod, Kaminka, Strumilova, Buchach, Horodenka, Rava Ruska and several families from the Carpathian Ukraine. Settlement in the municipality of Bosanska Gradiška began in 1900. The settlement of Ukrainians in Prijedor municipality lasted from 1890 to 1912. These were immigrants from the municipalities of Ternopil, Brod and Drohobych. At the same time, a small number of families moved to the municipality of Bosanski Novi. Emigration to Sarajevo, the place favored by Ukrainian intelligentsia, and Zavidovici and Varesh, chosen by the working class due to mines and factories, should be noted. In the first settlements, Banja Luka was not a mass immigration area, but as a cultural, educational and economic center, it has become a significant center of Ukrainians since 1900. Mass migration from other Bosnian colonies began. Many came because they did not like the taxes, so they bought smaller properties for their own funds or sought better paying jobs. The more affluent came for the education of children and other reasons. There are no published statistics on the number of immigrated Ukrainians, and from available sources it can be fairly confidently concluded that by 1914, 12-14 thousand Ukrainians and about 4 thousand Poles from Galicia had immigrated [4].

\section{THE ROLE OF CHURCH AND CULTURAL LIFE IN PRESERVING NATIONAL IDENTITY}

Initially, the Ukrainian settlers were distributed in small groups in a hundred inhabited places within the distance of over $150 \mathrm{~km}$. The settlers were mostly poor peasants and small craftsmen. Most were literate. However, there were those who were illiterate, there were no highly educated people, not even teachers or priests, among the settlers. In such circumstances it was very difficult to organize life, especially social life. The family was the basic pillar and the backbone of authentic preservation of language, customs, traditions, religion and religious rituals. The family was also the cradle in which love and awareness of belonging to their people were nurtured. Children gathered around the houses and trained in basic literacy. The houses also served religious services. The settled Ukrainians were of the Greek Catholic faith and very devout believers. Initially, they had many problems to meet their religious needs, such as baptisms, weddings, funerals, and worship. They were served by Roman Catholic (Croatian or Polish) or Serbian Orthodox priests. It was not uncommon that the believers were attracted to the Orthodox Church by the priests, with the promise that they would be baptized, buried, etc. Thus, there have been cases of conversion to a different faith. For example, in the parish of Cerovljani, because of the long absence of a Greek Catholic priest, about 1,000 people followed Latin rites. In Petrovo Selo, within the same eparchy, 40 Ukrainians felt Roman Catholics by faith and German by nationality [5].

However, parishes soon began to be established and churches were built. The first parish was founded in Prnjavor in 1897, and the church was built in 1912. Then the parish was established in Devetina in 1900, Stara Dubrava in 1906, Derventa in 1907, Banja Luka and Kozarac in 1910 etc. An important role in protecting the national identity of Ukrainians was played by the Studena Monastery, built in Kamenica in 1907. The monastery in Pozarevac was burned in 1914 together with church. It was later rebuilt and definitively abolished in 1924 . The monastery was a significant religious, educational and cultural center. By the mid-1930s, ten parishes were founded and 26 churches were built, 
mostly by their own means. The parishes comprised 92 settlements and gathered over 11,000 believers. However, due to dispersion over a large area, part of the Ukrainian population remained outside religiously organized backgrounds. The Ukrainian Greek Catholic Church played a very important role in preserving the national identity of Ukrainians in Bosnia. At first it was the backbone of spiritual, educational and cultural life.

The first reading rooms were organized around the houses. It was not until 1909 that the first reading room was established in Prnjavor. She was the impetus and role model for opening such reading rooms in other settings. Reading rooms were a gathering places where books and newspapers from the previous environment were collectively read. In addition, singing societies and amateur theater groups soon began to gather, stage shows and parties began to be organized etc.

After the migration of Ukrainian intelligence to the Kingdom of Yugoslavia in the 1920s, contacts were established with organized Ukrainian societies in Belgrade, Zagreb and Ljubljana. From 1933 to 1941 the Ridne Slovo newspaper was printed in the Ukrainian language. From 1934 to 1941, the illustrated Annual Calendar was published. The First World War significantly changed life and slowed down its progress, and the Second World War fundamentally changed the position of the newly arrived Ukrainian population [5].

It was not easy for Ukrainians to preserve their identity. Despite many pressures, Ukrainians still managed to maintain and nurture their identity. In the early years, they successfully organized cultural and educational activities. The Cultural Society "Prosveta" was founded, and later the "Ukrainian Society". Shevchenko's evenings were organized, Ukrainian songs were sung, lyrics were read, folklore was being cherished, libraries and reading rooms were being opened. Shevchenko's evenings grew into Days of Ukrainian Culture in the Kingdom of Yugoslavia. The Drama Section of the society nurtured a top-notch drama repertoire and very successful concerts were organized in cooperation with the Serbian Singing Society. Education later established branches in Novi Sad, Veliki Bečkerek, Subotica, Šid and other places. In Smederevo, the Kobzar Society was established with a drama and tamburitza section, and Ukrainian amateur drama sections existed in Šabac, Pozarevac, Zaječar and some other smaller places. Student Youth was founded by the Ukrainian Student Society. It is worth noting that the companies received financial support from the Kingdom of Yugoslavia. In this migration there were many top intellectuals (professors, lawyers, doctors, pharmacists, artists and others) who left a deep mark on the education, art and culture of Serbia between the two world wars [6].

\section{MOVING TO SERBIA}

Shortly after the Ukrainians immigrated to Bosnia, contacts with Rusyns in Vojvodina were individually established. They were linked by Greek Catholic faith and the relative closeness of the language. There were mixed marriages, most often in Vojvodina. Individual relocations from Bosnia to Vojvodina were constant. Somewhat more intense after the creation of the Kingdom of Serbs, Croats and Slovenes, and especially before the beginning and during the Second World War. On the whole it was not a mass phenomenon [7].

The migration of Ukrainians from Bosnia to Serbia took place after World War II in 1945 and 1946. The newly created state, the Federal People's Republic of Yugoslavia, colonized Vojvodina with partisan families from Bosnia, Lika, Banija, Herzegovina, 
Dalmatia, Montenegro and Serbia. With this colonization, several dozen Ukrainian families were settled. Ukrainians settled in Rusko Selo, Novi Kozarci and Krajišnik in Banat, then in Budisava, Kovilj, Kać, Bački Jarak, Zmajevo, Ratkov and other places in Bačka, several families settled in Beška, Dobanovci and Soko Salaš (near Zemun) in Srem. Given the vast area where they were colonized and the small number of families in some places, Ukrainians were a very small ethnic community in all these places [8].

The migration of Ukrainians from Bosnia to Vojvodina, guided by the search for better living conditions, was very intense in the 1950s and 1960s. Although Ukrainians settled individually and in an unorganized manner, a large number of their families were settled as well. Thus, a clear Ukrainian diaspora was created in Vojvodina [8].

\section{THE CURRENT SITUATION OF UKRAINIANS IN VOJVODINA}

According to the censuses after WWII, and the earlier ones, it was not possible to establish the number of Ukrainians in Vojvodina. The Ukrainian national minority was not specifically mentioned, but was classified under the common name "Rusyns, Ruthenians, Ukrainians", or by religious affiliation. This information did not give a true picture of the number of Ukrainians and it confused the users of this information. Only after the 1971 censuses did the Ukrainians gain nationality status and have their own checkboxes in the lists.

The movement of the number of Ukrainians in Serbia is shown in Figure 1. According to the 2011 census, there were 4,903 Ukrainians living in Serbia and 5,354 in 2002, which is a decrease of about $8 \%$. However, this indicator only gives partially accurate results on population movements. In fact, this a flotant ethnic group, as citizens from one census to another answered differently when asked about nationality. In fact, from 1971 to 2011, the total number of Ukrainians in Serbia decreased by about 13\% [9].

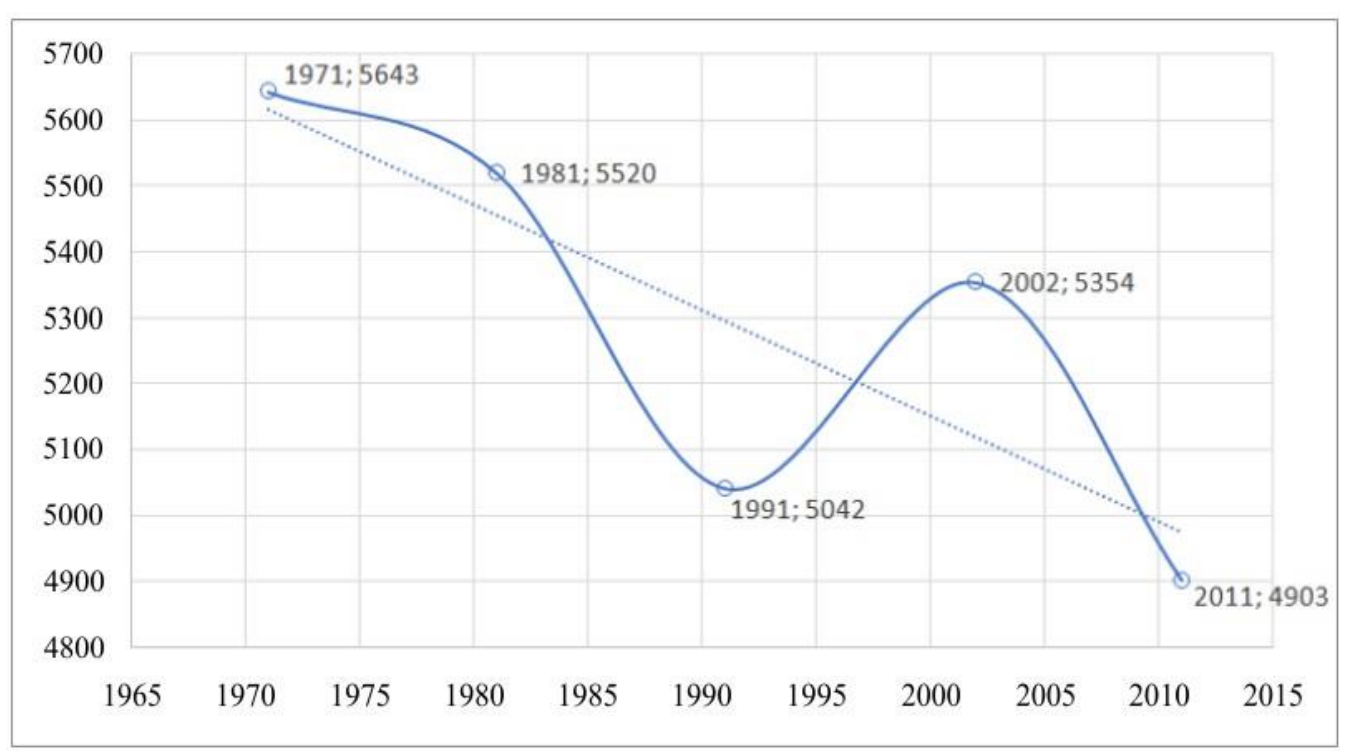

Figure 1. Movement of Ukrainians in Serbia from 1971 to 2011. [9]

In $2011,4,202$ or $86 \%$ of the total number of Ukrainians in Serbia lived in Vojvodina. In other parts of Serbia there were only 701 Ukrainians while $60 \%$ of them lived in Belgrade. The extent to which migration to Vojvodina was disorganized and spontaneously manifested can be seen in the fact that Ukrainians still live in all municipalities of Vojvodina and in over 200 populated places today. 
Over time, Ukrainian population started to form groups. In the municipalities of Kula, Vrbas, Sremska Mitrovica, Novi Sad and Inđija there are about $85 \%$ of all Ukrainians. The largest population is located in the municipalities of Kula $(1,290)$, followed by Vrbas (836), Sremska Mitrovica (534), Novi Sad (484) and Inđija (about 391) etc. [9]

The spatial distribution of Ukrainians in Vojvodina is shown on Figure 2. It is noted that the highest concentration of Ukrainians is in South Bačka, West Bačka and Srem districts, while other Vojvodina districts are sporadically populated. This grouping could be positively evaluated. The relatively small geographical distance of the settlements where Ukrainians live in large numbers allows for easier communication, cooperation in organizing cultural events and creating a sense of community that is very important for preserving national identity [9].

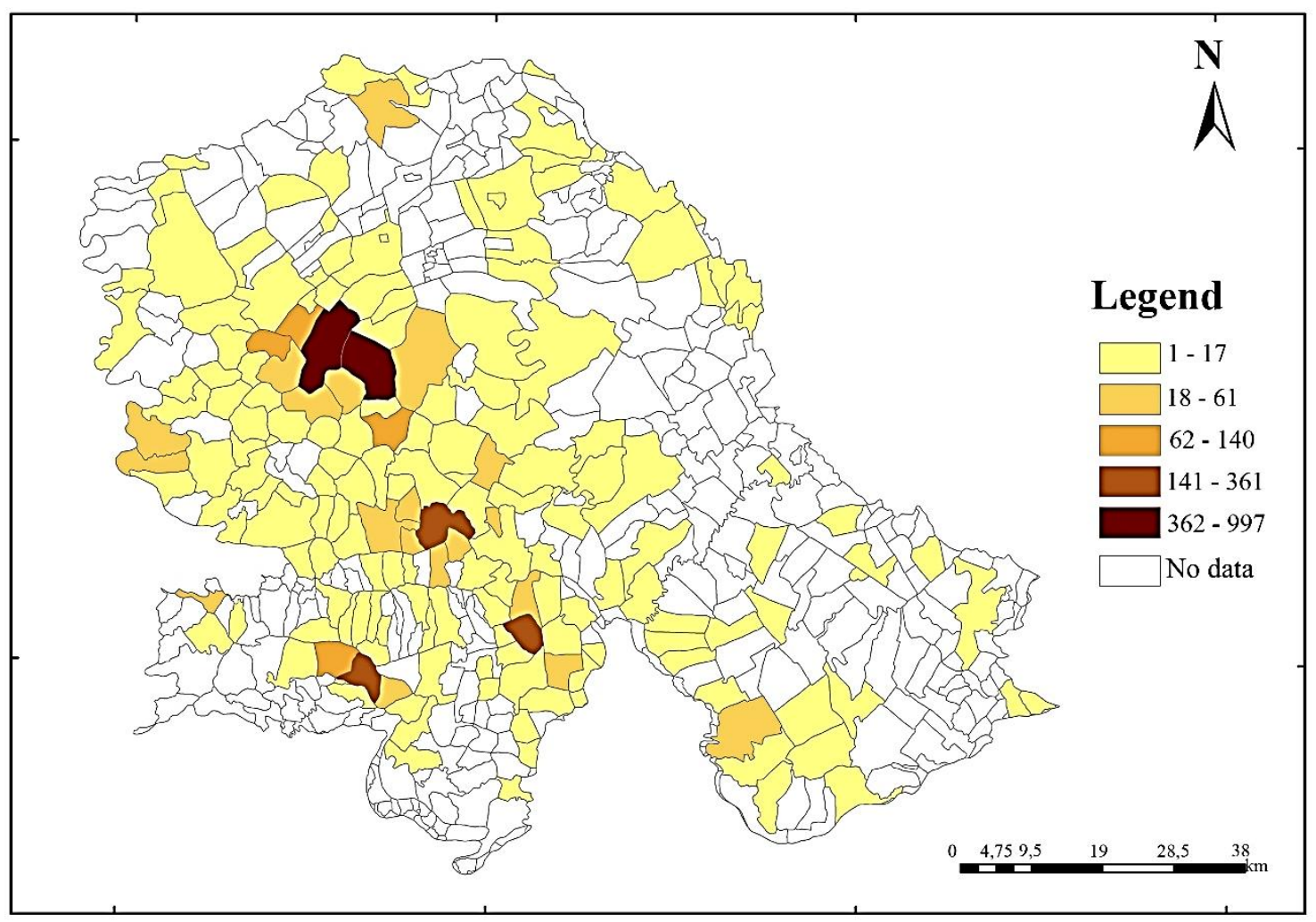

Figure 2. Spatial distribution of Ukrainians in Vojvodina in 2011. [9]

According to the results of the 2011 census, the average age of Ukrainians was as high as 45.0 years (the average for the Republic of Serbia is 42.2 years). The deep demographic age of Ukrainians in Serbia is certainly indicated by the fact that the share of the population aged 65 and over is significantly higher than the share of children under 15 (10.0\% under $15,21.0 \% 65$ and over). In the same census year, the aging index was 2.07, an extremely high value given that the population is considered to start demographically aging when the aging index exceeds the limit of 0.4. Disorders in the age structure of Ukrainians in Serbia are the result of low fertility and emigration. According to the 2011 census, the average number of live births of Ukrainians who gave birth was 2.05 , which is slightly less than the number required for an easy replacement of generations (2.1), but more than the national average (1.96). The average age of the mother giving birth to her first child was 23.8 years [10]. 
These demographic indicators point to a not very clear picture of the future of the Ukrainian population in Serbia. A further decline in population and an increase in average age can be expected. In such circumstances, Ukrainians face difficult tasks in their efforts to preserve their national identity. One way of this struggle is to foster language and culture within cultural institutions.

The cultural associations of the Ukrainian national community are "Ivan Senjuk" in Kula, "Karpati" in Vrbas, "Kolomejka" in Sremska Mitrovica, "Kobzar" in Novi Sad and "Kalina" in Inđija. The Ukrainians also have their own magazine called Ridne slovo. The first issue of the magazine was published in July 2005 and up to now it is published once a month. In addition to newspapers, Ridne slovo is registered for publication in the Ukrainian language and other journals, brochures, literary works, professional manuals and other publications. The founder of the Ridne Slovo newspaper-publisher is the National Council of the Ukrainian National Minority. The Ridne slovo newspaper, as the official gazette of the Ukrainian community in the Autonomous Province of Vojvodina, is funded by the Executive Council of AP Vojvodina. The Association for Ukrainian Language, Literature and Culture "Prosveta" was founded in 1989 and it organizes summer schools of Ukrainian studies in Vojvodina and Ukraine.

\section{CONCLUSION}

The division of the SFRY further shattered the homogeneity of the Ukrainian national community. In addition, frequent migrations and changes of place of residence, a small number of families in one place, conversion to the Orthodox or Catholic faith, a large number of mixed marriages, the absence of native-language schools, a small number of cultural and artistic societies, etc., are the reasons why the third, and especially the following generation of Ukrainians, born in the former Yugoslavia or Vojvodina, does not speak their native language. Forgetting the mother tongue also contributes to the disappearance of the awareness of belonging to one's national community. In these circumstances, the preservation of the national identity of Ukrainians in Serbia has been significantly threatened and questioned.

\section{Acknowledgement}

This paper is part of projects 142-451-2549/2019-01 and 142-451-2123/2019-04 funded by the Provincial Secretariat for Higher Education and Scientific Research of the Vojvodina Province, Serbia.

\section{REFERENCES}

[1] Zakamarok P. Istorija i tragovi Ukrajinaca u Sremu i Srbiji, Inđija, Udruženje SrpskoUkrajinskog prijateljstva, UKUD Kalina, 2017.

[2] Jankulov B. Pregled kolonizacije Vojvodine u 18. i 19. veku, Novi Sad, Marica Srpska, 1961.

[3] Ćelap L. Kolonizacija zaporoških Kozaka u današnjoj Vojvodini u 18. stoleću, Zbornik radova Matice srpske za društvene nauke, 24, 122-130, 1959.

[4] Ćelap, L. Prilog proučavanju kolonizacije Vojvodine krajem XVIII veka, Zbornik Matice srpske za društvene nauke, 29, 79-88, 1961.

[5] Украинцы народ и култура, Москва - Киев, Роосииская Академия наук и Национална Академия наук Украиная, 2000.

[6] Ефименко А. Ј. Историја украјинског народа, Београд, Институт за политичке студије, 1999. 
[7] Просалової В. А. Українська діаспора: літературні постаті, твори, біобібліографічні відомості, Донецьк, Східний видавничий дім, Донецьке відділення НТШ, Український культурологічний центр, 2012.

[8] Zakamarok P. UKUD Kalina Inđija, 10 godina od osnivanja i rada, Inđija, Ukrajinsko kulturno-umetničko društvo Kalina, Udruženje Srpsko-Ukrajinskog prijateljstva, 2015.

[9] Popis stanovništva, domaćinstava i stanova 2011. u Republici Srbiji, Stanovništvo Republike Srbije po nacionalnoj pripadnosti (posebna obrada podataka), Beograd, Republički zavod za statistiku, 2016.

[10] Đurić V., Tanasković D., Vukmirović D., Lađević P. Etnokonfesionalni i jezički mozaik Srbije, Popis stanovništva, domaćinstava i stanova 2011. u Republici Srbiji, Beograd, Republički zavod za statistiku, 2014. 